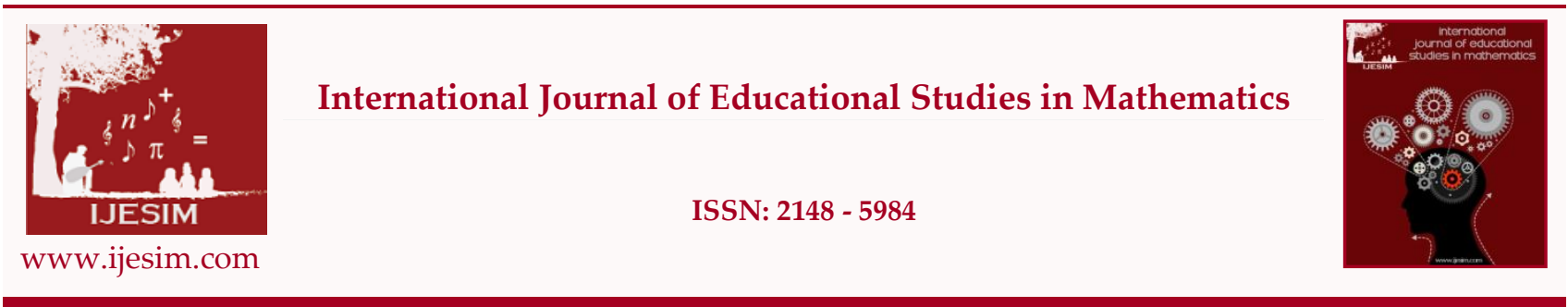

\title{
Teachers' Beliefs about Mathematical Problem Solving
}

\author{
Veli Tarhan ${ }^{1}$
}

Hasan Tekin Ada Anatolian High School, Denizli, TURKEY

The purpose of the study is to investigate the teachers' beliefs which are about mathematical problem solving. In this study as a method, for investigating problem of the research descriptive survey method was used. In the research, was tried to determine teachers' beliefs about mathematical problem solving. For this purpose, The Belief Survey on Mathematical Problem Solving (BSMPS), which has 39 items, is utilizing, beliefs are investigated in terms of 6 different sub dimensions. There are 119 classroom teachers, 17 science and technology teachers, 34 mathematics, 8 physics, 6 chemistry, and 8 biology teachers in totally 192 teachers, in research sample. As a result of the analysis it was seen that generally teachers have high beliefs in solving problems. Besides, when sub dimensions are examined, it is seen that some opinions of teachers toward mathematical problem solving are not mature yet and also some ideas are not at expected level.

Keywords:

problem solving, beliefs, mathematics education

(C) 2015 IJESIM. All rights reserved

Article History:

Received 04.05.2015 Received in revised form 23.07.2015 Accepted 16.09.2015 Available online 20.10.2015

\section{Extended Summary}

\section{Purpose}

Integrating problem solving to all mathematics curriculum makes the teachers' beliefs on problem solving throughout math teaching gain importance. This study is important, for the reason that teachers' beliefs have an impact on both class activities and also teaching problem solving. In this study, the aim is to lay out the teachers' beliefs which is about problem solving special subject of mathematics, and which affects the teachers' general objectives in math teaching. To find out these beliefs of teachers can be a resource for innovation studies in mathematics teaching and its programs and for forming up the inner training programs prepared for teachers. The subject of this study, for all these reasons, is considered to be worth researching. The datum of research is collected with the help of "The Belief Survey on Mathematical Problem Solving (BSMPS)" developed by Kayan(2007). This survey includes six opinions which are the importance of understanding, solutions of problems, following steps determined in advance while solving problem, problems taking up time to solve, to use different methods of solving, the deal of problem solving, and benefiting from technology while solving problem. The evaluation of the answers given by the teachers to BSMPS survey is made by using means which is measure of central tendency and standard deviation which is measure of the central span. Some topics, attracting attention in the tables constituted for every one of the sub problems, have been interpreted by selecting. Besides for unrelated measures Kruskal Wallis H-Test is

\footnotetext{
${ }^{1}$ Corresponding author's address: Hasan Tekin Ada Anatolian High School, Denizli, TURKEY

Telephone: +905057756385

Fax: +90 2582126979

e-mail: velitarhan@hotmail.com

DOI: http://dx.doi.org/10.17278/ijesim.2015.01.004
} 
used to understand whether the BSMPS points indicates remarkable differences according to branch of teachers.

\section{Results}

As a result of the analysis it was seen that generally teachers have high beliefs in solving problems. After examining each items individually, it is remarkably seen that some item doesn't have points at expected level. Some beliefs of teachers towards solving problems contradict with the problem and problem solving knowledge. When sub dimensions are examined, it is seen that some opinions of teachers toward mathematical problem solving are not mature yet and also some ideas are not at expected level. For example, to have the opinion that problem solving is directly related to the arithmetical operation skills, is thought provoking. The aim of the mathematic courses, during the problem solving process, is not solely to make students gain operation skills. Operation skills take its part at the end of problem solving skills; even recently used educational technology is a candidate to take place of these skills. Teachers have the attitude that knowing the proper problem solving methods in advance is enough to solve all types of problems. These approaches of teachers are in contrast the philosophy of situation to be a problem. If a student knows in advance how to solve a mathematical question, it is no longer a problem but a practice. Considering the same sub-dimensions when we look at article 12 teachers have the conviction of learning problem solving is related to bearing in mind the correct solving methods of problem. In the light of these results, it can be concluded that teachers joining this research have misleading opinion of memorizing which is a fragment of traditional education.

\section{Discussion}

Today, the important role of beliefs in mathematics education is now unarguable. The effect of mathematics education on other subjects; and also other subjects effect on, even indirect, mathematics is fact which cannot be ignored. For this reason, in National Educational Assembly's foundations giving formal education. The cooperation among the all teachers teaching different subjects is continuously pointed out at meetings. Related to all, the beliefs of teachers, especially math teachers, about mathematical problem solving gain importance. Laying out these beliefs can be the subject and resource for the upcoming inner training courses.

\section{Conclusion}

With the help of these inner training courses, what problem solving is and what it is not; problem solving is not an effort but is a thinking process can be explained and conveyed to teachers. Moreover researchers which reflect the teachers', teaching social sciences, points of view can lay out interesting results. Looking through their point of view can lead us to a finding which we, mathematicians, cannot see. Besides for the further qualitative researches on both the beliefs of teachers' teaching mathematics and science and the beliefs of teachers teaching social sciences, and a research which gives more detailed information can be done. 


\section{Öğretmenlerin Matematiksel Problem Çözmeye Yönelik İnançları*}

\section{Veli Tarhan ${ }^{1}$}

Hasan Tekin Ada Anadolu Lisesi, Denizli,TüRKIYE

ÖZ

$\mathrm{Bu}$ çalışmanın amacı, öğretmenlerin matematiksel problem çözmeye yönelik inançlarını incelemektir. Bu çalışmada yöntem olarak, araştırma problemini incelemek üzere betimsel tarama modeli kullanılmıştır. Araştırmada öğretmenlerin matematiksel problem çözme hakkındaki inançları belirlenmeye çalışılmıştır. Bu amaçla 39 maddelik Matematiksel Problem Çözme İnançları (M.P.Ç.İ.) ölçeği kullanılarak; inançlar ölçeğin 6 farklı alt boyutları açısından incelenmiştir. Araştırmanın örnekleminde 119 sınıf öğretmeni, 17 fen ve teknoloji öğretmeni, 34 matematik, 8 fizik, 6 kimya ve 8 biyoloji öğretmeni olmak üzere toplam 192 öğretmen bulunmaktadır. Analizler sonrasında öğretmenlerin genel olarak problem çözmeye yönelik olumlu inanışta olduğu sonucuna ulaşılmıştır. Bunun yanında, alt boyutlar incelendiğinde öğretmenlerin matematiksel problem çözmeye yönelik bazı görüşlerinin olgunlaşmadığı, birtakım fikirlerinin ise istenen düzeyde olmadığı görülmüştür.

Anahtar Kelimeler:

problem çözme, inançlar, matematik eğitimi.

(c) 2015 IJESIM. Tüm hakları saklıdır.

Makale Tarihçesi:

Alındı04.05.2015 Düzeltilmiş hali alındı 23.07.2015 Kabul edildi 16.09.2015 Çevrimiçi yayınlandı 20.10.2015

\section{Giriş}

Bir öğrenciye, "Matematiksel problem çözme deyince aklınıza ilk olarak ne gelir?" diye sorulsa, ilk önce, dolup boşalan havuzlar, başladığı işi bırakan işçiler, başkasının kazandığı paranın kârı, zararı, hiç kullanamadığı arabaların hızlarının hesabı gibi cevaplar almak olasıdır. Karışım problemleri, mum soruları, yüzde hesapları, kesir problemleri gibi, belli sınıflandırmalarla oluşturulmuş alt başlıklar, akıllarına gelen ilk tanımlamalar olabilir. Aslında problem çözme, bırakın matematik dersinin sadece bir konusu olmayı, bütün derslerin işlenişinde temel oluşturabilir.

Eğitimin hedefleri, etkili problem çözme becerilerini geliştirmeye odaklanmalıdır (Naser, 2008). 21. yüzyılın öğretim yönteminin problem çözme olduğunun bilinmesi gerekir. Bu nedenle problem ve problem çözmenin yapısı ile problem çözmede başarının artırılması pek çok eğitimci ve psikolog tarafından üzerinde çalışılan bir konudur (Kılıç ve Samanc1, 2005). Bu bağlamda öğrencilere problem çözme becerisinin kazandırılmasında, sadece matematik dersi öğretmenlerinin değil, bütün öğretmenlerin bu beceriyi geliştirmek amaçlı çalışmalar yapması yararlı olacaktır.

$\mathrm{Bu}$ durum problem çözme becerilerini öğrencilere kazandırma konusunda, matematik öğretmenlerinin üzerindeki görevi hafifletmeye yetmez. Problem çözme, matematik derslerinin ve matematik etkinliklerinin ayrılmaz bir parçası olmalıdır. Problem çözme, başlı başına konu değil, bir süreçtir. Bu süreç, bütün matematik programına entegre edilerek problem çözme becerilerinin öğrenilmesi ve kullanılması hedeflenmiştir (Meb, 2005). Bu anlayışla oluşturulan matematik eğitimi sürecinde, matematiksel problem çözme için ayrı bir başlık atmaya, sınıflandırmalar yaparak, kazanımlar yazmaya gerek olmayabilir. Belki de bu nedenle Meb 2005 programında 12 ders saati süre ayrılan problemler için, sadece 1 kazanım yazılmıştır. 9. sınıf matematik dersi öğretim programında fonksiyonlar ve doğal sayılardan sonra en yüksek oranı, \% 9 ile problemler konusu almaktadır. Ancak ne yazık ki pratikte böyle görünen bu durumun uygulamada nasıl olduğu, tartışma konusudur. Lise matematik programının geliştirmeyi hedeflediği; matematiksel model kurabilme, matematiksel düşünme, problem çözme, iletişim kurma, ilişkilendirme ve akıl yürütme becerilerinden birisi problem çözmedir (Meb, 2005). Ayrıca matematiksel modelleme ve ispatlama da birer ileri problem çözme becerisi olarak ele alınacak olursa problem çözme, tüm matematik dersi öğretim

\footnotetext{
${ }^{*}$ Bu çalışma, Anadolu Öğretmen Liseleri II. Ulusal Eğitim Bilimleri Kongresinde sunulmuş bildirinin genişletilmiş halidir.

Sorumlu yazarın adresi: Hasan Tekin Ada Anadolu Lisesi, Denizli,TÜRKIYE

Telefon:0 5057756385

Faks:0 2582126979

e-posta: velitarhan@hotmail.com
} 
programının genel merkezi amaçlarından biri olarak karşımıza çıkar. Bu anlayışla oluşturulduğu düşünülen Meb 2013 programında problem çözmeye, matematiksel modelleme ile birlikte birçok kazanımda yer verilmiştir. Program öğrenme ve öğretme sürecinde kullanılacak olan problemlerin mümkün oldukça öğrencilerin günlük hayatında gereksinim duyduğu/duyabileceği konularla ilgili, ilginç ve mümkün olduğunca da gerçekçi olması gerektiğini belirtmiştir (Meb, 2013).

Gerçekçi Matematik Eğitiminin (Realistic Mathematics Education) ilk savunucularından olan Freudenthal'e göre, matematik öğretimi gerçek hayat problemleri ile başlamalı ve öğrenme şekli problem çözme sürecinin öğrenilmesi şeklinde olmalıdır. Öğrencinin matematikte bilgiye kendisinin ulaşmasının sağlanması gerekmektedir. Freudenthal, "Matematiksel aktiviteyi, konusu matematikten veya gerçek hayattan alınan bir problem için çözüm arayışı, çözüm için düzenlemenin yapılması (s. 225)" olarak açıklamaktadır (Graveimeijer'den aktaran Aydoğdu ve Ayaz: 2009). Bilimsel ve teknolojik gelişmelerin akıl almaz bir hızla gerçekleşmesi günümüz insanın her geçen gün, kendisi için yeni olan kavramlar ile karşılaşmasına neden olmaktadır. Bu noktada matematik eğitiminin, bireylerin bu değişimlere ayak uydurmasına yardımcı olması anlamlıdır. O halde bireyin karşılaşacağı durumların "hangileri problemdir, hangileri değildir" sorularına, problemin tanımı yapılarak açıklık getirilebilir.

\section{Problem Nedir?}

Klass'a göre John Dewey problemi, insan zihnini karıştıran, ona meydan okuyan ve inancı belirsizleştiren her şey olarak tanımlamaktadır (Baykul, 2004). Problem kişide çözme arzusunu uyandıran ve çözüm prosedürü hazırda olmayan fakat kişinin bilgi ve deneyimlerini kullanarak çözebileceği durumlardır. Böylece birisi için problem olan bir durum bir başkası için problem olmayabilir (Olkun ve Toluk, 2009). Genel olarak problem, matematiksel düşüncelerin uygulamalarını içeren etkinlikler olarak tanımlanabilir (Baki, 2006). Dubai'de yapılan Palmiye Adaları, adaları inşa eden mühendisler için başlangıçta bir problemdi. Çünkü bu yapı daha önce hiçbir mühendis tarafından yapılmamıştı ve çözüm prosedürü hazırda yoktu. Ama artık o mühendisler için aynı projeyi yapmak problem olmaktan çıkmıştır. Eğer insan bir problem ile daha önceden karşılaşmış ve onu daha önceden çözmüş ise, o problem kişi için bir sorun olmaktan çıkabilir. Öyleyse problemin kişi için yeni ve orjinal olması gerekir (Gelbal, 1991). Morgan'a (1995) göre problem, temelde bireyin bir hedefe ulaşmada engelleme (frusration) ile karşılaştığ 1 bir çatışma (conflict) durumudur (Morgan'dan aktaran Soylu ve Soylu, 2006). Kısacası bir problemin varlığından söz edebilmek için şu üç halin oluşmuş olması gerekir:

- Sorunla karşılaşan bireyin çözüme ilişkin belli bir amacının olması gerekir,

- Sorunun çözümü için başlangıçta birey tarafından bilinen bir yolun olmaması gerekir,

- Bireyin çözüme giden yoldaki engelleri kaldırmak ve çözüme ulaşmak için düşünsel çaba ve gayret sarf etmesi gerekir (Bayazit ve Aksoy, 2009).

Yaşamın anlamlı bir biçimde sürdürülebilmesi, gereksinimlerin en kısa ve doğru yoldan karşılanması ve değişik dönemlerde karşılaşılan problemlere uygun çözüm üretilmesine bağlıdır. Bu süreçte birey, karşılaştığı olay ve olguları araştırır ve dener. Onlarla ilgili tahminlerde bulunur, hipotezler kurar ve kurduğu hipotezleri test eder (Alkan ve Bukova, 2005). Öğretimin her kademesinde öğrencilerin önüne konulan problemler ve karşılaştığı bu engelleri ortadan kaldırmak için yapılandırdığı problem çözme süreçleri çok önemlidir. Çünkü birey aslında kendi bilgi birikimini kullanarak, düşünsel süreçlerinin sonucunda bir ürün ortaya koyar ve bir nevi yeni bir şeyler üretmiş olur.

\section{Problem Çözme}

Problem çözme matematiğin merkezindedir. Oysa problem çözme becerisi göründüğü gibi değildir (Sweller, Clark ve Kirschner, 2010). Problem çözme “Ne yapılacağının bilinmediği durumlarda yapılması gerekeni bilmektir." Problem çözme sadecebir doğru sonuç bulma olarak algılanmakla birlikte daha geniş bir zihinsel süreci ve becerileri kapsayan bir eylemdir (Altun, 2008)Problem çözmenin değişik tanımları yapılmıştır. Heppner ve Krouskopf (1987) problem çözmeyi karışık içsel ve dışsal istek ve arzuların uyumu için bilişsel ve etkili davranışsal süreçler, Bingham (1998), belli bir amaca ulaşmak için karşılaşılan güçlükleri ortadan kaldırmaya yönelik bir dizi çabayı gerektiren bir süreç, Morgan (1999) ise, karşılaşılan engeli aşmanın en iyi yolunu bulmak olarak tanımlamaktadır. Problem çözme, kişinin problemi hissedişinden ona çözüm buluncaya kadar geçirdiği bir süreçtir (Güçlü, 2003). Bu süreç, öğrencilerin birden fazla matematiksel kavramları bir bağlamda keşfetmelerini sağlar (Lowrie \& Logan, 2006).Problem çözme, bireyin amaç, ihtiyaç, 
değer, inanç, beceri, alışkanlık ve tutumları ile ilgilidir. Problem çözme, bir amaca erişmekte karşılaşılan güçlükleri yenme sürecidir, bu da bilgiyi kullanarak ve buna orijinallik, yaratıcılık ya da hayal gücünü ekleyerek çözüme ulaşma süreci olarak açıklanabilir (Buluç, Kuru ve Taneri, 2010). Bu süreçleri ünlü matematikçi George Polya (1945) 4 adımda tanımlamışır. Polya'nın 4 adımdan oluşan problem çözme modeli şu stratejileri içermektedir: a) Problemi anlamak, b) Bir plan tasarlamak, c) Planı uygulamak, d) Geriye bakıp, düşünmek. Herbir aşama soruların kullanımı ve açıklamalarla daha iyi tanımlanır (Griffin \& Jitendra, 2009). Alkan (1998) problem çözme basamaklarını;

- Problemin anlaşılması

- Probleme uygun bir matematiksel yapı kurulması

- Oluşturulan yapının incelenmesi

- İşlem yapımı ve sonucun denenmesi

- Yeni örnekler verilmesi

olarak sıralamıştır. Birey tüm bu basamakları rahatça tırmanabiliyorsa problemi çözebilir (Alkan, 1998). Problem çözme için önerilen bu adımlar birbirlerinden çok keskin çizgilerle ayrılmaz. Bu adımların gerçekleştirilmesi her zaman doğrusal bir yolda izlemeyebilir. Adımlar arasında ileri geri gidişler olabilir. Öğrenciler kendi anlama ve biliş seviyelerine göre aynı probleme değişik yaklaşımlarla değişik çözümler üretebilirler (Olkun ve Toluk, 2009). Problem çözme yeteneği belki de insan neslinin varlığını sürdürebilmesi için gerekli en temel yetenektir (Altun, 2008). Bu yeteneğin geliştirilmesi insan nesli için oldukça önemlidir ve bu beceriyi geliştirmek başta matematik dersinin olmak üzere, bütün derslerin üzerine düşen görevdir. NCTM (National Council of Teachers of Mathematics)'in 2000' de 9-12. sinıflar matematik dersi müfredatı için belirlemiş olduğu 10 standarttan biri, problem çözmedir. Formal eğitimin amaçlarından biri bireye problem çözme becerisi kazandırma olduğundan, öğretmenlerin problem çözmeye yönelik inançları önem kazanmaktadır.

$\mathrm{Bu}$ nedenle bu çalışmada farklı branşlardaki öğretmenlerin matematiksel problem çözmeye yönelik inançları ölçülmek istenmiştir. Eğitim araştırmaları açısından inançlar, bireyin çevresindeki olgular için geliştirdiği ve zihninde sahip olduğu kavrayışlar, temel varsayımlar ve savlar olarak tanımlanmaktadır (Richardson'tan aktaran Kayan ve Çakıroğlu, 2008). Matematik öğretmenlerinin, matematiğin doğası ve öğretimi hakkındaki inançları, aslında matematik öğrenimi sürecinde birçok faktörün belirlenmesinde önemli rol oynamaktadır (Baydar ve Bulut, 2002). Literatürde, öğretmen inançlarının sınıf içi öğretim uygulamalarını şekillendirdiği ve sınıflarda gözlemlenebilen öğretim aktiviteleri aslında öğretmenlerin kafasında gerçekleşen ve gözlemlenemeyen bir sürecin sonucu olduğu vurgulanmaktadır (Boonyaprakob’tan aktaran Aydın, Baki, Yıldız ve Köğce, 2009). Örneğin, bazı matematik öğretmenleri matematiği çok iyi düzenlenmiş kesin bir bilgi kümesi gibi görürken, bazıları matematiğin dünyayı açıklamak için bir yol ya da bir araç gibi düşünülmesi gerektiğine inanabilir. Başka bir grup matematik öğretmeni ise matematiğin şiir gibi, müzik gibi bir sanat dalı olarak değerlendirilmesinden yana olabilir (Baydar ve Bulut, 2002). Bu durum, aynı resme bakarak ressamın tablosuna katmaya çalıştığı anlamı yorumlamaya çalışan insanların durumu ile eşleştirilebilir. Her birinin aynı tabloya biçecekleri değer farklı olabilir.

Literatür deki problem çözmeye yönelik inançları konu alan çalışmalara bakıldığında şunları ifade etmek mümkün olabilir. Kayan ve Çakıroğlu (2008) çalışmalarında genel olarak ilköğretim matematik öğretmen adaylarının problem çözme ile ilgili pozitif görüşlere sahip olduklarını, ancak hesaplama becerilerinin önemi ve problem çözerken önceden belirlenmiş adımları takip etmenin gerekliliği gibi bazı gelenekçi görüşlere sahip olduklarını saptamışlardır. Yılmaz (2007), 10. Sınıf öğrenciler ile yaptı̆̆ı çalışmasında problem okunduktan ve cevaplandıktan sonra, problem hakkındaki inançların farklılığını, öğrencilerin, bekledikleri gibi sade veya alışılmış formatta sonucu olmayan problemlerin cevabında şüpheye düştüğünü tespit etmiştir. Ayrıca bu inançların, yeterli bilgi ve beceriye sahip olsalar da, öğrencilerin problem çözümlerindeki performanslarına negatif etki ettiğini gözlemlemiştir. Xenofontosve Andrews (2008), Kıbrıslı 3 matematik öğretmeni ile yaptıkları durum çalışmalarında öğretmenlerin problem çözmeye yönelik inançları ile yetenekleri arasındaki ilişki için karışık bir durum olduğunu bunun doğrusal bir fonksiyon olarak sunulamayacağını ortaya koymuşlardır. Callejo ve Vila (2009), öğrencilerle yaptıkları çalışmalarında benzer bir sonuca ulaşmışlardır. 61 öğrenci ile yaptıkları önceki çalışmadan seçtikleri 2 öğrenci için elde ettikleri sonuçlara göre problem çözmeye yönelik inanç sistemleri ile yaklaşımları arasında 
karmaşık bir ilişki olduğuna dair bulgular ortaya koymuşlardır. Aydın vd. (2008), yalnızca bir matematik öğretmeninin matematik bilgi, matematiği öğrenme ve öğretme ile ilgili görüssleri hakkında bir kesit sunmak için yaptıkları araştırmalarında katılımcı öğretmenin matematik bilginin doğası, değerlendirme ve matematik öğretimi açısından bir takım katı fikirlere sahip olduğu sonucuna varmışlardır. Aikins, Duer ve Hutter (2005) 7. ve 8. düzey 1200 öğrenciye uyguladıkları, Epistemolojik İnanç Anketi, İndiana Matematik İnanç ve Matematiğin Kullanılışlığı ölçekleri ile topladıkları verilerin ışığında, stratejik çalışmaya olan inanç, veya bunun eksikliğinin, ilköğretim ikinci kademe öğrencilerinin matematiksel problem çözme hakkındaki inançları bakımından çok önemli olduğunu belirtmişlerdir. Uğurluoğlu (2008), yüksek lisans tezinde ilköğretim 7. ve 8. sınıf düzeyinde 3556 öğrenciye "Öğrenci Bilgi Formu", "Matematik Tutum Ölçeği", "Problem Çözme Tutum Ölçeği" ve "Matematik ve Problem Çözme İnanç Ölçeği" araçlarının uygulanması ile geniş örnekleme sahip bir araştırma yapmıştır. Araştırma sonuçlarına göre, öğrencilerin matematik başarı seviyesi, gelir seviyesi, anne ve babanın öğrenim seviyesi arttıkça, yaşanılan yerleşim yeri büyüdükçe, öğrencilerin matematik ve problem çözmeye ilişkin tutumları ve inançları olumlu yönde gelişmektedir. Ayrıca öğrencilerin matematik ve matematik problemlerine ilişkin inançları, cinsiyete göre kız öğrencilerin lehine; matematik ve problem çözmeye ilişkin öz yeterlilik inançları, cinsiyete göre erkek öğrencilerin lehine anlamlı düzeyde farklılaştığı sonucuna ulaşmıştır. Duatepe Paksu (2008), 40 tanesi matematik öğretmeni olan 324 öğretmenin matematik hakkındaki inançlarını belirlemek ve matematik inançlarının branş ve cinsiyete göre olası değişimlerini analiz etmek amacı ile 20 maddelik bir ölçek kullanarak yaptı̆̆ı çalışmasında, her ne kadar öğretmenler birkaç maddede problem çözme olarak adlandırılan bakış açısıyla tutarlı inançlara sahip olsalar da genel olarak enstrümantalist olarak sınıflanan geleneksel bir bakış açısına sahip oldukları sonucuna ulaşmıştır. Bu çalışmada matematik öğretmenlerinin diğer branşlara göre daha geleneksel bir bakış açısına sahip oldukları sonucu dikkat çekici olarak değerlendirilebilir. Hacıömeroğlu (2011), Epistemolojik İnanç Ölçeği ve Matematiksel Problem Çözmeye İlişkin İnanç Ölçeği kullanarak 204 sınıf öğretmeni adayından topladığı veriler ile yaptığı araştırmasında, öğretmen adaylarının matematiksel problem çözmeye ilişkin inançlarında öğrenmenin çabaya ve yeteneğe bağlı olduğuna ilişkin inançlarının etkili olduğunu, sınıf öğretmeni adaylarının problem çözmeye ilişkin inançlarını yordamada epistemolojik inançlarının önemli bir rolü olduğunu tespit etmiştir.

Problem çözme sürecinin bütün matematik müfredatına kaynaştırılmış olması, matematik öğretimi sürecinde öğretmenlerin problem çözme hakkındaki inançlarına önem kazandırmaktadır. Öğretmenlerin inançlarının sınıf içi etkinliklerinde ve dolayısıyla problem çözmenin öğretiminde etkili olması sebebiyle bu çalışma önemlidir. Bu çalışmada amaç, öğretmenlerin matematik öğretiminin genel hedeflerini etkileyen, matematiğin özel konusu olan problem çözmeye yönelik inançlarını ortaya koymaktır. Öğretmenlerin bu inançlarını belirlemek, matematik öğretimine ve öğretim programlarına yönelik yenilik çalışmalarına, öğretmenler için düzenlenen hizmet içi eğitim çalışmalarının şekillenmesine kaynak oluşturabilir. Bu çalışmanın araştırma konusu, bu nedenlerle araştırmaya değer bulunmuştur.

\section{Araştırmanın Problemi}

Bu çalışmada araştırmanın problemi; "Öğretmenlerin matematiksel problem çözmeye yönelik inançları nelerdir?" olarak oluşturulmuştur. Öğretmenlerin inançlarını belirlemek için ölçekteki; problem çözümünün anlaşılmasının önemine, problem çözerken önceden belirlenmiş adımların izlenmesine, cevaplaması zaman alan problemlere, farklı çözüm yolları kullanmaya, problem çözmenin sınıfta ele alınışına ve problem çözerken teknolojiden faydalanmayla ilgili alt boyutlara yönelik inançlar analiz edilmiştir.

\section{Yöntem}

Bu çalışmaya konu olan problemi araştırmak amacı ile betimsel tarama modeli kullanılmıştır. Tarama modelleri geçmişte ya da halen var olan bir durumu var olduğu şekli ile betimlemeyi amaçlayan araştırma yaklaşımıdır. Araştırmaya konu olan olay, birey ya da nesne, kendi koşulları içinde ve olduğu gibi tanımlanmaya çalışılır. Onları, herhangi bir şekilde değiştirme, etkileme çabası gösterilmez (Karasar, 2002). Betimsel tarama modeli yaklaşımına göre, elde edilen veriler, daha önceden belirlenen temalara göre özetlenir ve yorumlanır. Ortaya çıkan temaların ilişkilendirilmesi, anlamlandırılması ve ileriye yönelik tahminlerde bulunulması da, araştırmacının yapacağı yorumların boyutları arasında yer alabilir (Yıldırım ve Şimşek, 2005). 


\section{Çalışma Grubu}

Çalışma grubu Denizli ili, Tavas ilçesi ve ilçeye bağlı köy ve kasabalardaki ilköğretim ve ortaöğretim okullarında çalışan 92 bay, 100 bayan toplam 192 öğretmenden oluşmaktadır. Öğretmenlerin branşları; matematik, fizik, kimya, biyoloji, sınıf, fen ve teknoloji öğretmenliği olarak seçilmiştir. Bu branşların matematiksel problem çözme ile diğer branşlara nazaran daha ilgili oldukları düşünüldüğü için, bu branşların araştırmanın örneklemini oluşturmaları uygun görülmüştür. Bunun yanında ilk ve ortaöğretimde problem çözmenin kapsamı ve sunuluş biçimi biraz farklılık göstermektedir. Ancak, problemin çözüm yolu önceden bilinen alıştırma ve soru olarak algılanmaması, problem çözmeye algoritmik ve kural temelli yaklaşılmaması, problem çözmenin süreç olduğu anlayışı gibi temel prensiplere her iki programda da yer verilmiştir. Öğrencilere kazandırılmak istenen problem çözme becerileri ve problem çözme stratejileri hemen hemen aynıdır. Bu bağlamda bu iki grubun matematiksel problem çözmeye yönelik inançlarının birlikte değerlendirilmesi anlamlı bulunmuştur. Çalışma grubundaki öğretmenlerin branşlarına göre dağılımları aşağıda (Tablo 1) verilmiştir.

Tablo 1. Öğretmenlerin Branşa Göre Dağılımları ve Yüzdeleri

\begin{tabular}{lcc}
\hline Branş & $\mathbf{n}$ & $\mathbf{\%}$ \\
\hline Matematik & 34 & 17.7 \\
Fizik & 8 & 4.2 \\
Kimya & 6 & 3.1 \\
Biyoloji & 8 & 4.2 \\
Sınıf & 119 & 62 \\
Fen ve Tek. & 17 & 8.9 \\
Toplam & 192 & 100 \\
\hline
\end{tabular}

\section{Veri Toplama Aracı}

Araştırmanın verileri Kayan (2007) tarafından geliştirilen 'Matematiksel Problem Çözmeye Yönelik İnanışlar Ölçeği' (MPÇİ) aracıllı̆̆ ile toplanmıştır. Ölçek hazırlanırken önceden bu alanda kullanılmış dört farklı ölçme aracından yararlanılmıştır (Emenaker, 1996; Hart, 2002; Kloosterman \& Stage, 1992; Zollman \& Mason, 1992; Akt. Kayan ve Çakıroğlu, 2008). Orijinalleri İngilizce olan bu ölçeklerdeki maddelerin seçiminde Türk öğretmen adaylarının eğitim kültürüne ve araştırma kapsamında ele alınan problem boyutlarına uygunlukları göz önünde bulundurulmuştur. Bunlara ek olarak problem çözmenin sınıfta ele alınışına ilişkin yeni öğretim programındaki görüşleri yansıtan maddeler de araştırmacılar tarafından eklenmiş olması sebebi bu ölçeğe başvurulmasında etkili olmuştur. (Kayan ve Çakıroğlu, 2008). Ölçek, problem çözümünün anlaşılmasının önemi, problem çözerken önceden belirlenmiş adımların izlenmesi, cevaplaması zaman alan problemler, farklı çözüm yolları kullanma, problem çözmenin sınıfta ele alınışı ve problem çözerken teknolojiden faydalanma olmak üzere altı görüşü içermektedir. Ancak bu görüşler faktör analizi sonucu ortaya çıkan alt boyutlar olarak algılanmamalıdır. Çünkü Kayan ve Çakıroğlu (2008), ölçeğin faktör yapısını, nihai uygulamadaki 244 kişilik veriyi kullanarak yaptığı faktör analizi sonucu kontrol etmiş ve kuramsal olarak oluşturulan madde gruplarının ölçek boyutu olarak doğrulanamadığını görmüştür. Bu nedenle aynı görüşü inceleyen maddeleri gruplandırarak madde bazında analizlerin yapılmasını uygun görmüştür. Kayan (2007)'nin geliştirdiği ölçekte Cronbach Alpha güvenirlik katsayısı 0.87 olarak bulunmuştur. $\mathrm{Bu}$ ölçeğin bizim örneklememizdeki verilere dayanılarak yapılan güvenirlik analizinde Cronbach Alpha güvenirlik katsayısı 0,76 olarak hesaplanmıştır. Kayan (2007) ölçeğin geliştirilmesi aşamasında 40'ar öğretmen adayının katılımıyla gerçekleştirilen iki aşamalı pilot çalışma yapmıştır. Birinci aşamada elde edilen bilgiler doğrultusunda ölçekte gerekli düzeltmeleri yapmış; daha sonra başka bir 40 kişilik gruba uygulayarak ölçeğe son halini vermiştir. Ölçekte 22' si olumlu, 17'si olumsuz inanç ifadelerinden oluşan toplam 39 tane madde bulunmaktadır. Maddeler puanlanırken, olumlu ifadeler 'Tamamıyla Katılıyorum (5)', 'Tamamıla Katılmıyorum (1)' olacak şekilde puanlama yapılmıştır. Olumsuz ifade edilen maddelerin puanlaması ters çevrilerek yapılmıştır. Buna göre, her bir maddenin alabileceği en düşük ortalama puan 1, en yüksek ortalama puan ise $5^{\prime}$ tir. Ayrıca ölçeğin araştırmamızda kullanımı konusunda araştırmacıdan elektronik posta aracılı̆̆g ile izin alınmıştır. 
Kayan, yüksek lisans tezi için 2005-2006 eğitim yılı bahar döneminde İç Anadolu ve Karadeniz bölgesindeki illerden seçilen 5 üniversitenin ilköğretim matematik öğretmenliği bölümlerine devam eden 244 son sınıf öğretmen adayından topladığı verilerin sonuçlarını 2008 yılında yayınlamıştır. Kayan (2008), çalışmasında öğretmen adayları ve sadece ilköğretim matematik bölümünde okuyanların MPÇílerini incelerken, bizim çalışmamızda halen görevde ve farklı branşlarda olan öğretmenlerin MPÇíleri incelenmiştir. Bu anlamda çalışmamız farklılık göstermektedir. Çalışmanın verilerinin toplanması, Denizli ili Tavas İlçe Milli Eğitim Müdürlüğü'nden resmi izin alınarak yapılmıştır. İlçe milli eğitim bize verilerin toplanması aşamasında destekte sağlamıştır. Kurum bünyesinde oluşturulmuş "Kurum-Net" isimli network ağı aracıllğı ile aynı anda kuruma bağlı bütün okullara veri gönderilebilmektedir. İlçe milli eğitime sunulan ölçek formu, ilçe milli eğitimce üst yazı hazırlanarak Kurum-Net aracılığı ile bütün okullara gönderilmiş, ilgili öğretmenlerin MPÇİ ölçeğini doldurmaları ve formları ilçe müdürlüğüne teslim etmeleri sağlanmıştır. Ayrıca ilçe merkezindeki bütün okullar benim çalıştığım kurum müdürü ile birlikte tek tek dolaşılarak çoğaltılan formlar okul müdürlüklerine teslim edilmiş, köylerdeki okul müdürlükleri yine benim çalıştığım kurum müdürü tarafından tek tek aranmış, formun doldurulması ile ilgilenmeleri istenerek, çalışmaya destek olmaları sağlanmıştır.

\section{Verilerin Analizi}

$\mathrm{Bu}$ çalışmada istatistiksel analizler SPSS 13.0 paket programı kullanılarak yapılmıştır. Öğretmenlerin MPÇİ ölçeğine vermiş olduğu cevapların değerlendirilmesi, merkezi eğilim ölçüsü aritmetik ortalama ve merkezi yayılma ölçüsü standart sapma kullanılarak yapılmıştır. Her bir alt problem için oluşturulan tablolardan dikkati çeken bazı maddeler seçilerek yorumlanmıştır. Bu yorumlamalar sırasında verilen yüzde oranları, maddelerin frekans tablolarından elde edilen oranlardır. Frekans tabloları bilgi kirliliği oluşturmamak amacı ile bu araştırmada sunulmamıştır. Bunun yanında MPÇİ puanlarının branşlara göre anlamlı farklılık gösterip göstermediğine bakmak için ilişkisiz ölçümler için Kruskal Wallis H-testi kullanılmıştır.

\section{Bulgular}

Bu bölümde; öğretmenlerin MPÇİ ölçeğine vermiş oldukları cevapların istatistiklerine yer verilmiştir. Verilerin değerlendirilmesinde merkezi eğilim ölçüsü aritmetik ortalama ve merkezi yayılma ölçüsü standart sapma kullanılmıştır. Kayan vd. (2008) tarafından oluşturulan gruplar baz alınarak, grup grup her bir maddenin ortalama ve standart sapması tablolaştırılmıştır. Bu bağlamda tablolarda dikkati çeken maddelerin istatistiki verileri yorumlanmıştır.

Tablo 2'de öğretmenlerin ölçeğe verdiği cevaplardan "problem çözümünün anlaşılmasının önemi" alt boyutunun ortalama ve standart sapmaları verilmiştir. Tablo' da madde 6'nın dikkat çektiği görülmektedir. Öğretmenlerin \% 93'ünün (4.52 ortalama ve 0.772 standart sapma ile), bir problemin çözümünün niye doğru olduğunu anlamayan kişinin sonucu bulsa da aslında tam olarak o problemi çözmüş sayılmayacağını, düşündükleri sonucuna ulaşılmıştır. Bunun yanında analiz sonuçları, öğretmenlerin \% 85'inin (4.04 ortalama ve 0.991 standart sapma ile), bir problemin çözümünü bulmanın o problemi anlamaktan daha önemli olduğu, fikrine katılmadıklarını göstermektedir (Madde 12).

Tablo 2. Problem Çözümünün Anlaşılmasının Önemi

\begin{tabular}{|c|c|c|}
\hline $\begin{array}{l}\text { Maddeler } \\
\end{array}$ & Ortalama & Std. Sap. \\
\hline $\begin{array}{l}\text { 1.*Matematiksel problem çözmede bir yöntemin kişiyi doğru cevaba } \\
\text { ulaştırması, nasıl veya niye ulaştırdığından daha önemlidir. }\end{array}$ & 3.33 & 1.267 \\
\hline $\begin{array}{l}\text { 6. Bir problemin çözümünün niye doğru olduğunu anlamayan kişi sonucu } \\
\text { bulsa da aslında tam olarak o problemi çözmüş sayılmaz. }\end{array}$ & 4.52 & 0.772 \\
\hline $\begin{array}{l}\text { 12.* Bir problemin çözümünü bulmak o problemi anlamaktan daha önemlidir. } \\
\text { 18. Bir çözümü anlamaya çalışmak için kullanılan zaman çok iyi } \\
\text { değerlendirilmiş bir zamandır. }\end{array}$ & $\begin{array}{l}4.04 \\
4.27\end{array}$ & $\begin{array}{l}0.991 \\
0.646\end{array}$ \\
\hline $\begin{array}{l}\text { 24. Bir çözümde öğrencinin mantıksal yaklaşımı, çözümün doğru olmasına } \\
\text { kıyasla daha çok takdir edilmelidir. }\end{array}$ & 4.19 & 0.695 \\
\hline $\begin{array}{l}\text { 29. Bir matematik problemini çözerken doğru cevabı bulmanın yanında bu } \\
\text { cevabın niye doğru olduğunu anlamak da önemlidir. }\end{array}$ & 4.43 & 0.683 \\
\hline
\end{tabular}


Tablo 3'de öğretmenlerin, problem çözümü esnasında önceden belirlenmiş adımların izlenmesi, alt boyutuna yönelik verdiği cevapların betimsel istatistikleri verilmiştir. Öğretmenlerin ankete verdikleri puanlardan, \% 80'ninin (2.74 ortalama ve 0.982 standart sapma ile) matematikçilerin problemleri çözerken önceden bilinen çözüm kalıplarını nadiren kullandıkları fikrine katılmadıkları (Madde 7), \% 77'sinin (3.73 ortalama ve 0.906 standart sapma ile) her matematiksel problemin önceden bilinen bir çözüm yolunun takip edilerek çözülemeyeceğini düşündükleri sonucu çıkmaktadır (Madde 37). Birbirini destekler görünen bu sonuçların yanında, öğretmenlerin \% 75'inin çözüm yollarının akılda tutulmasını, problem çözmede faydalı olarak görmeleri dikkat çekicidir (Madde 30).

Tablo 3. Problem Çözülürken Önceden Belirlenmiş Adımların İzlenmesi

\begin{tabular}{lc}
\hline Maddeler & Ortalama \\
\hline 2.* Uygun çözüm yollarını bilmek bütün problemleri çözmek için yeterlidir. & 2.53 \\
7. Matematikçiler problemleri çözerken önceden bilinen çözüm kalıplarını & 2.74 \\
nadiren kullanırlar. & 1.134 \\
13. Problem çözmeyi öğrenmek problemin çözümüne yönelik doğru yolları & 2.48 \\
akılda tutmakla ilgilidir. & 3.982 \\
19. İlgili formülleri hatırlamadan da problemler çözülebilir. & 3.66 \\
25. Öğrencilerin matematik problemleri çözebilmeleri için çözüm yollarını & 2.89 \\
önceden bilmesi gerekir. & 1.134 \\
30. Çözüm yollarını akılda tutmak problem çözmede çok faydalı değildir. & 2.60 \\
34. Belirli bir çözüm yolunu kullanmadan bir matematik problemini çözmek & 3.24 \\
mümkün değildir. & 1.073 \\
37. Her matematiksel problem önceden bilinen bir çözüm yolu takip edilerek & 1.222 \\
çözülemeyebilir. & 0.906 \\
\hline
\end{tabular}

${ }^{*}$ Negatif ifadeli maddedir. Ters çevrilerek puanlanmıştır.

Tablo 4'de öğretmenlerin "cevaplaması zaman alan problemler" hakkındaki inançlarına yönelik analiz sonuçları verilmiştir. Bu sonuçlar 1şı̆̆ında öğretmenlerin \% 70'inin(2.76 ortalama ve 1.104 standart sapma ile) matematikte iyi olmanın, problemleri çabuk çözmeyi gerektirdiğini düşündükleri anlaşılmaktadır (Madde 20). Bunun yanında \% 90'ının (4.30 ortalama ve 0.774 standart sapma ile) en zor matematik problemlerinin bile üzerinde ısrarla çalışıldığında çözülebileceği, fikrine sahip oldukları görülmektedir.

Tablo 4. Cevaplaması Zaman Alan Problemler

\begin{tabular}{|c|c|c|}
\hline Maddeler & Ortalama & Std. Sap. \\
\hline $\begin{array}{l}\text { 3. Bir matematik probleminin çözümünün uzun zaman alması rahatsız } \\
\text { edici değildir. }\end{array}$ & 3.03 & 1.157 \\
\hline $\begin{array}{l}\text { 8.* Bir problemin nasıl çözüleceğini anlamak uzun zaman alıyorsa o } \\
\text { problem çözülemez. }\end{array}$ & 4.08 & 0.848 \\
\hline $\begin{array}{l}\text { 14. En zor matematik problemleri bile üzerinde israrla çalışıldığında } \\
\text { çözülebilir. }\end{array}$ & 4.30 & 0.774 \\
\hline 20.* Matematikte iyi olmak, problemleri çabuk çözmeyi gerektirir. & 2.76 & 1.104 \\
\hline
\end{tabular}

* Negatif ifadeli maddedir. Ters çevrilerek puanlanmıştır.

Tablo 5'de öğretmenlerin, matematiksel problemlerde farklı çözüm yollarını kullanma ile ilgili görüşleri için analiz sonuçları yer almaktadır. Analiz sonuçlarında öğretmenlerin \%97'sinin (4.54 ortalama ve 0.612 standart sapma ile) bir problemi çözmenin tek doğru yöntemi olduğuna inanmadığı görülmektedir (Madde 9). Öğretmenlerin, \% 82'sinin (4.01 ortalama ve 0.923 standart sapma ile) farklı çözüm yollarını öğrenmenin, öğrencilerin kafasını karıştırabileceğini düşünmedikleri saptanmıştır (Madde 38). 
Tablo 5. Farklı Çözüm Yolları Kullanma

\begin{tabular}{|c|c|c|}
\hline Maddeler & Ortalama & Std. Sap. \\
\hline $\begin{array}{l}\text { 4. Bir problemi, öğretmenin kullandığı veya ders kitabında yer alanlar } \\
\text { dışında yöntemler kullanarak çözmek mümkündür. }\end{array}$ & 4.46 & 0.662 \\
\hline 9.* Bir problemi çözmenin sadece bir doğru yöntemi vardır. & 4.54 & 0.612 \\
\hline $\begin{array}{l}\text { 15. Öğretmenin çözüm yöntemini unutan bir öğrenci aynı cevaba ulaşacak } \\
\text { başka yöntemler geliştirebilir. }\end{array}$ & 4.33 & 0.704 \\
\hline $\begin{array}{l}21 .^{*} \text { Verilen herhangi bir problemin çözümünde tüm matematikçiler aynı } \\
\text { yöntemi kullanır. }\end{array}$ & 4.17 & 0.792 \\
\hline $\begin{array}{l}\text { 26. Bir öğrenci, problemi bir yoldan çözemiyorsa başka bir çözüm yolu } \\
\text { mutlaka bulabilir. }\end{array}$ & 3.99 & 0.789 \\
\hline $\begin{array}{l}\text { 31.* Bir matematik öğretmeni, problemlerin çözümlerini tam olarak sınavda } \\
\text { isteyeceği şekilde öğrencilere göstermelidir. }\end{array}$ & 2.99 & 1.292 \\
\hline $\begin{array}{l}\text { 35. Bir matematik öğretmeni, öğrencilerine bir soruyu çözdürürken çok } \\
\text { çeşitli yönlerden bakabilmeyi de göstermelidir. }\end{array}$ & 4.60 & 0.568 \\
\hline 38.* Farklı çözüm yolları öğrenmek, öğrencilerin kafasını karıştırabilir. & 4.01 & 0.923 \\
\hline
\end{tabular}

${ }^{*}$ Negatif ifadeli maddedir. Ters çevrilerek puanlanmıştır.

Tablo 6'da öğretmenlerin, problem çözmenin sınıfta ele alınışına inançlarını yansıtan analiz sonuçları verilmiştir. Öğretmenlerin \%95' inin (1.81 ortalama ve 0.788 standart sapma ile) problem çözmenin matematikte işlem becerileri ile ilgili olduğuna inandığ ${ }_{1}$ belirlenmiştir (Madde 16). Bunun yanında öğretmenler, \% 93 katılım göstererek (4.36 ortalama ve 0.641 standart sapma ile), öğrencilerin problem çözme yaklaşımlarını ve tekniklerini diğer öğrenciler ile paylaşmaları gerektiğini düşünmektedirler (Madde 22).

Tablo 6. Problem Çözmenin Sınıfta Ele Alınışı

\begin{tabular}{lcc}
\hline Maddeler & Ortalama & Std. Sap. \\
\hline 10. Problem çözme matematik müfredatının tamamına yansıtılmalıdır. & 3.83 & 0,997 \\
16. Problem çözme matematikte işlem becerileri ile doğrudan ilgilidir. & 1.81 & 0.788 \\
22. Öğrenciler, problem çözme yaklaşımlarını ve tekniklerini diğer & 4.36 & 0.641 \\
öğrenciler ile paylaşmalıdır. \\
$\begin{array}{l}\text { 27. Öğrencilere problemlerin çözüm yollarını göstermek onların } \\
\text { keşfetmesini beklemekten daha iyidir. } \\
\begin{array}{l}\text { 32. Matematik derslerinde öğrencilerin problem kurma becerileri } \\
\text { geliştirilmelidir. }\end{array}\end{array}$ 3.78 \\
\hline${ }^{*}$ Negatif ifadeli maddedir. Ters çevrilerek puanlanmıștır.
\end{tabular}

Negatif ifadeli maddedir. Ters çevrilerek puanlanmışır.

Tablo 7'de son olarak öğretmenlerin, matematiksel problemleri çözerken teknolojiden faydalanma inançlarına yönelik analiz sonuçları verilmiştir. Öğretmen adaylarının \%93'ünün (4.64 ortalama ve 0.687 standart sapma ile) matematik öğretiminde uygun teknolojik araçların öğrenciler için her zaman erişilebilir olması gerektiğine inandıkları (Madde 5), \% 78'inin (4.04 ortalama ve 0.908 standart sapma ile) teknolojik araçların, öğrencilerin matematik öğrenme becerilerine zarar vermediğine inandıkları sonucuna ulaşılmıştır (Madde 36).

Tablo 7. Problem Çözerken Teknolojiden Faydalanma

\begin{tabular}{lcc}
\hline Maddeler & Ortalama & Std. Sap. \\
\hline $\begin{array}{l}\text { 5. Matematik öğretiminde uygun teknolojik araçlar öğrenciler için her zaman } \\
\text { erişilebilir olmalıdır. }\end{array}$ & 4.64 & 0.687 \\
11.* Problem çözerken teknolojik araçlar kullanmak bir tür hiledir. & 3.94 & 0.974 \\
17. Teknolojik araçlar, problem çözmede faydalıdır. & 4.04 & 0.830 \\
$\begin{array}{l}\text { 23. Öğretmenler, teknolojiyi kullanarak öğrencilerine yeni öğrenme ortamları } \\
\text { oluşturmalıdır. }\end{array}$ & 4.41 & 0.673 \\
28.* Problem çözerken teknolojiyi kullanmak zaman kaybıdır. & 4.14 & 0.776 \\
33. Teknolojiyi kullanmak öğrencilere çalışmalarında daha çok seçenek sunar. & 4.17 & 0.737 \\
36.* Teknolojik araçlar, öğrencilerin matematik öğrenme becerilerine zarar verir. & 4.04 & 0.908 \\
39. Öğrenciler, uygun bir şekilde teknolojiyi kullanırlarsa matematiği daha & 4.10 & 0.852
\end{tabular}

\footnotetext{
${ }^{*}$ Negatif ifadeli maddedir. Ters çevrilerek puanlanmıştır.
} 
Tablo 8'de araştırmaya katılan öğretmenlerin M.P.Ç.İ puanlarının branş değişkenine göre anlamlı bir fark gösterip göstermediğini belirlemek amacıyla ikiden fazla grup için gerçekleştirilen Kruskal Wallis- $\mathrm{H}$ testi sonuçları verilmiştir. Analiz sonuçlarına göre, M.P.Ç.İ puanları branş değişkenine göre anlamlı farklılık göstermektedir $(\mathrm{p}<.05)$.

\begin{tabular}{lllll} 
Tablo 8. Öğretmenlerin M.P.Ç.I. Puanlarının Branşlara Göre Kruskal Wallis-H Testi \\
\hline Branş & $\mathbf{n}$ & Ortalama & $\boldsymbol{x}^{\mathbf{2}}$ & $\mathbf{p}$ \\
\hline Matematik & 34 & 120,01 & & \\
Fizik & 8 & 67,25 & & \\
Kimya & 6 & 108,92 & & \\
Biyoloji & 8 & 65,31 & 13.749 & 0.017 \\
Sinıf & 119 & 90,93 & & \\
Fen ve Tek. & 17 & 112,53 & & \\
\hline
\end{tabular}

Tablo 9'da farkın anlamlılığını sınamak için Mann Whitney U testi yapılmıştır. Bu testler aracılığı ile yapılan matematik-fizik, matematik-biyoloji, matematik-sınıf karşılaştırılmalarında matematik öğretmenlerinin, fizik-fen ve teknoloji karşılaştırılmasında fen ve teknoloji öğretmenlerinin M.P.Ç.İ puanlarının daha yüksek olduğu tespit edilmiştir.

Tablo 9. Öğretmenlerin M.P.Ç.İ. Puanlarının Mann Whitney U Testi Sol
\begin{tabular}{lll}
\hline Branş & $\mathbf{n}$ & Ortalama \\
\hline Matematik & 34 & 23,66 \\
Fizik & 8 & 12,31 \\
\hline Matematik & 34 & 23,68 \\
Biyoloji & 8 & 12,25 \\
\hline Matematik & 34 & 94,72 \\
Sinıf & 119 & 71,94 \\
\hline Fizik & 8 & 8,63 \\
Fen ve Tek. & 17 & 15,06 \\
\hline
\end{tabular}

\section{Sonuç ve Öneriler}

Analizler sonrasında öğretmenlerin genel olarak problem çözmeye yönelik yüksek inanışta olduğu sonucuna ulaşılmıştır. Maddelerin tek tek incelenmesi sonucunda kimi maddelerin puanlarının istenen düzeyde olmaması dikkat çekicidir. Öğretmenlerin matematiksel problem çözmeye yönelik bazı inançları problem ve problem çözme bilgilerine ters düşmektedir. Duatepe Paksu (2008), öğretmenlerin matematiğe yönelik inançlarını incelediği çalışmasında benzer olarak öğretmenlerin, birkaç maddede problem çözme olarak adlandırılan bakış açısıyla tutarlı inançlara sahip olduklarını, genelde enstrümantalist olarak sınıflanan geleneksel bir bakış açısı içerisinde bulundukları sonucuna ulaşmıştır. Kayan ve Çakıroğlu (2008) İç Anadolu ve Karadeniz bölgesindeki illerden seçilen 5 üniversitenin ilköğretim matematik öğretmenliği bölümlerine devam eden 244 son sınıf öğretmen adayı ile yaptıkları çalışmalarında benzer sonuca ulaşarak, öğretmen adaylarının, problem çözme ile ilgili olumlu sayılabilecek görüşlere sahip olduklarını belirlemişlerdir. Çalışma grubu kapsamındaki öğretmen adaylarının tamamının matematik branşında olduklarından, matematiğin doğasına ve problem çözmenin matematiksel düşüncedeki yerine dair deneyimlerinin bu sonucun bir nedeni olabileceğini belirtmişlerdir. Ancak bizim çalışmamızda matematik öğretmenlerinin çalışma grubunun sadece \% 17.7'sini oluşturmasına rağmen benzer puanların ortaya çıması, öğretmenlerin matematiksel problemlere yönelik olumlu görüşlere sahip olmalarının, matematik öğretmeni olmalarına bağlanmasının doğru olmayabileceğini göstermektedir. Bu kuşkuyu test etmek amacı ile yapılan Kruskal-Wallis-H testi sonucu Kayan ve Çakıroğlu'nun tartışmalarını destekler biçimindedir. Genelde çıkan yüksek inanış puanlarının branş özelinde incelenmesi sonucunda da matematik branşı öğretmenlerinin ortalamalarının anlamlı olarak diğer branş öğretmenlerinden yüksek çıktığı görülmüştür. Ancak bunun yanında fen ve teknoloji dersi öğretmenleri lehine de olumlu görüş ortaya çıkmıştır. Bunun yanında genel olarak bakıldığında, örneklemin sayısal dersler ve sınıf öğretmenlerinden oluşması, bu 
öğretmenlerin uyguladıkları müfredatlar aracılı̆̆ı ile direk olarak, sıklıkla matematiksel problemlerle muhatap olmaları zihinlerinde sahip oldukları pozitif kavrayışların sebebi olabilir. Bu düşüncenin aksine Duatepe Paksu (2008)' nun araştırmasında, matematiğe yönelik inançlar bakımından matematik öğretmenlerinin diğer branşlara göre daha geleneksel bir bakış açısına sahip olduklarını tespit etmiş olması farklı bir durumu ortaya koymaktadır.

Alt boyutlar incelendiğinde öğretmenlerin matematiksel problem çözmeye yönelik bazı görüşlerinin olgunlaşmadığı, birtakım fikirlerinin ise istenen düzeyde olmadığı görülmektedir. Örneğin, problem çözmenin aritmetik işlem becerileri ile doğrudan ilgili olduğu fikrinde olunması düşündürücüdür. Matematik sınıflarında problem çözme sürecinde öğrencilere kazandırmak istediğimiz yalnızca işlemsel beceriler değildir. Neyi, neden yaptıklarına karar verme, alternatifleri görme kendini değerlendirme ve en önemlisi farkındalık kazandırma hedeflerimizin başında gelmektedir (Çolak, Bulut ve Argün, 2005). İşlem becerisi, problem çözme sürecinin son aşamasında yer almaktadır. Hatta günümüzde kullanılan eğitim teknolojileri bu becerinin yerini almaya aday gözükmektedirler. Öğretmenler uygun çözüm yollarının önceden bilinmesinin bütün problemleri çözmek için yeterli olacağı inancındadırlar. Bu yaklaşım bir durumun problem olma felsefesine terstir. Eğer öğrenci karşılaştığı matematiksel bir sorunun çözüm yolunu önceden biliyorsa, onun için artık o problem değil alıştırmadır. Aynı alt boyutta 12. maddeye bakıldığında öğretmenlerimiz, problem çözmeyi öğrenmenin, problemin çözümüne yönelik doğru yolları akılda tutmakla ilgili olduğu kanısındadırlar. Bu sonuçlardan, çalışmaya katılan öğretmenlerin problem kavramı ile ilgili yanılgılara sahip olduğu ve halen gelenekselci eğitim anlayışının bir parçası olan ezberciliğin etkisinde oldukları düşünülebilir.

Matematik eğitiminde inançların oynadığı rolün önemi bugün artık tartışılamaz hale gelmiştir. Öğretmenlerin inançları üzerine yapılan araştırmalar gün geçtikçe artmakta ve derinleşmektedir (Aydın, vd., 2009, Baydar ve Bulut, 2002, Callejo ve Vila, 2009, Hacıömeroğlu, 2011, Kayan ve Çakıroğlu, 2008). İnançlar ve öğretmenlerin öğretim seçimleri üzerindeki etkisi, matematik eğitiminde yaygın araştırma konusu olmuştur (Xenofontos ve Andrews, 2008). Matematik eğitiminin, farklı branşlardaki derslere, farklı derslerin matematik eğitimine dolaylı da olsa etkisi yadsınamaz bir gerçektir. Bu sebeple milli eğitimin örgün eğitim veren kurumlarında, zümre ve şube öğretmenleri toplantılarında farklı branşlarla işbirliğine sürekli işaret edilmektedir. Bu bağlamda matematiksel problem çözmeye yönelik özellikle sayısal dersi öğretmenlerinin inançları önem kazanmaktadır. Bu inançların ortaya konulması, ileride yapılacak olan hizmet içi eğitimlere, seminer çalışmalarına konu ve kaynak oluşturabilir.

Bu eğitimler aracılığı ile mutlaka öğretmenlere problemin ne olduğunun, ne olmadığının, problem çözmenin bir hamle değil, düşünsel bir süreç olduğunun vurgulanması sağlanabilir. Araştırmacıların farklı branş öğretmenlerinin sayısal değerlerini yaklaşık tutmaları halinde, öğretmenlerin inançları açısından aralarındaki ilişkileri incelemeleri anlamlı olabilir. Ayrıca sözel dersleri yürüten öğretmenlerin, matematiksel problemlere bakış açılarını yansıtan araştırmalar ilginç neticeler ortaya koyabilir. Onların penceresinden bakmak, bizlerin göremediği bazı bulgulara ulaştırabilir. Bunların yanında, yapılacak olan araştırmalarda gerek sayısal, gerekse sözel ders öğretmenlerinin inançlarını inceleyen ve daha derin bilgiler veren nitel araştırmalara yer verilebilir.

\section{Kaynakça}

Aikins, S. M., Duer, O. K. ve Hutter, R. (2005). Epistemological Beliefs, Mathematical Problem-Solving Beliefs, and Academic Performance of Middle School Students. The Elementary School Journal.105(3). 289-304.

Alkan, H. \& Bukova-Güzel, E. (2005). Öğretmen Adaylarında Matematiksel Düşünmenin Gelişimi, Gazi Üniversitesi Eğitim Fakültesi Dergisi, Aralık 2005(3).221-236.

Altun, M. (2008). İlköğretim İkinci Kademede ( 6, 7 ve 8. Sınıflarda) Matematik Öğretimi, İstanbul: Aktüel Yayınları, ISBN: 975-2972-322.

Altun, M. ve Alkan, H. (Bölüm Yazarlığı), Editör; Prof. Dr. Aynur Özdaş, (1999). Anadolu Üniversitesi Açık Öğretim Fakültesi İlköğretim Öğretmenliği Lisans Tamamlama Programı Matematik Eğitimi, (1,2,3,4,7,8,9,10. Bölümler), Eskişehir: Açık Öğretim Fakültesi Yayınları,Yayınno: 591, ISBN 975-492-825-8.

Aydın, M., Baki, A., Yıldız, C. ve Köğce, D. (2009). Bir Matematik Öğretmeninin Matematik Bilgi ve Öğretimi Hakkındaki İnançları: Bir Özel Durum Çalışması. I. Uluslararası Türkiye Eğitim Araştırmaları Kongresi, Eğitim Araştırmaları Birliği Derneği, 1-3 Mayıs, Çanakkale.

Aydoğdu, M. ve Ayaz, M. F. (2009), Matematikte Öğrencilerin Problem Çözmeye Karsı Bakış Açılarının Ve Tutumlarının Ölçülmesi. I. Uluslararası Türkiye Eğitim Araştırmaları Kongresi, Eğitim Araştırmaları Birliği Derneği, 1-3 Mayıs, Çanakkale.

Baki, A. (2006). Kuramdan Uygulamaya Matematik Eğitimi. İstanbul: Bilge Matbaacılık.

Bayazit, İ. ve Aksoy, Y.(2009). Matematiksel Problemlerin Öğrenim ve Öğretimi. M.F. Özmantar, E. Bingölbali (Ed) İlköğretimde Matematiksel Kavram Yanılgıları ve Çözüm Önerileri. Ankara: PegemA. 
Baydar, S. C. ve Bulut, S. (2002). Öğretmenlerin Matematiğin Doğası ve Öğretimi ile İlgili İnançlarının Matematik Eğitimindeki Önemi. Hacettepe Üniversitesi Eğitim Fakültesi Dergisi. Sayı:23, 62-66

Baykul, Y. (2004). İlköğretimde Matematik Öğretimi 6. -8. Sınıflar için, Ankara: Pegema Yayıncılık.

Buluç, B., Kuru, O. ve Taneri, A. (2010). Sınıf Öğretmenliği Anabilim Dalında Okuyan Öğretmen Adaylarının Problem Çözme Becerileri, 9. Sınıf Öğretmenliği Eğitimi Sempozyumu. 20-22 Mayıs, Elazığ, s. 535-538

Callejo, M. L. ve Vila, A. (2009). Approach to mathematical problem solving and students' belief systems: two case studies. EducationalStudies in Mathematics.72: 111-126.

Çolak, H., Bulut, S. ve Argün, Z. (2005). Problem Çözme Sürecinde Yazma Tekniğinin Kullanımı ve Aday Matematik Öğretmenlerinin Bu Tekniğe Yönelik Görüşleri.

XIV. Ulusal Eğitim Bilimleri Kongresi Pamukkale Üniversitesi Eğitim Fakültesi. 28-30 Eylül. Denizli.

Gelbal, S. (1991). Problem Çözme. Hacettepe Üniversitesi Eğitim Fakültesi Dergisi, 6: 167-173.

Griffin, C. C. \& Jitendra, A. K. (2009). Word problem solving instruction in inclusive third grade mathematics classrooms. Journal of Educational Research, 102(3), 187-201.

Güçlü, Nezahat. (2003-Güz). "Lise Müdürlerinin Problem Çözme Becerileri", Milli Eğitim Dergisi, Sayı:160, 272-300.

Hacıömeroğlu, G. (2011). Sınıf Öğretmeni Adaylarının Matematiksel Problem Çözmeye. İlişkin İnançlarını Yordamada Epistemolojik İnançlarının İncelenmesi. Buca Eğitim Fakültesi Dergisi. Sayı:30, 206-220.

Karasar, N.(2002). Bilimsel Araştırma Yöntemi. Ankara: Nobel Yayın Dağıtım.

Kayan, F. (2007). İlköğretim Matematik Öğretmen Adaylarının Matematiksel Problem Çözmeye Yönelik İnanışları. (Yayınlanmamış yüksek lisans tezi). Ortadoğu Teknik Üniversitesi/Sosyal Bilimler Enstitüsü, Ankara.

Kayan, F. ve Çakıroğlu, E. (2008). İlköğretim Matematik Öğretmen Adaylarının Matematiksel Problem Çözmeye Yönelik İnançları. Hacettepe Üniversitesi Eğitim Fakültesi Dergisi, 35, 218-226

Kılıç, D., Samancı, O. (2005). İlköğretim Okullarında Okutulan Sosyal Bilgiler Dersinde Problem Çözme Yönteminin Kullanılışı. Kazım Karabekir Eğitim Fakültesi Dergisi, 11, 100-112.

Lowrie, T. \& Logan, T. (2006). Using spatial skills to interpret maps: Problem solving in realistic contexts. Australian Primary Mathematics Classroom, 12(4), 14-19.

Millı̂ Eğitim Bakanlığı (MEB) (2005). Ortaöğretim matematik dersi 9-12. Sınıflar öğretim program ve kılavuzu. M.E.B.: Ankara.

Millı̂ Eğitim Bakanlığı (MEB) (2013). Ortaöğretim matematik dersi 9-12. Sınıflar öğretim programı. M.E.B.: Ankara.

Naser, T. (2008). Problem Çözme Becerilerini Değerlendirmede Alternatif Yöntemler ve İlköğretim Matematikte Örnek Uygulama. (Yayınlanmamış yüksek lisans tezi). Yüzüncü yıl Üniversitesi/Fen Bilimler Enstitüsü, Van.

National Council of Teachers of Mathematics (NCTM). (2000). Principle standards for school mathematics. Reston, VA: Author.

Olkun, S. ve Toluk, Z. (2009). İlköğretimde Etkinlik Temelli Matematik Öğretimi. Ankara: Maya Akademi ve Danışmanlık.

Paksu, D. A. (2008). Comparing Teachers' Beliefs About Mathematics In Terms Of Their Branches And Gender. Hacettepe Üniversitesi Eğitim Fakültesi Dergisi, 35, 87-97

Soylu, Y. ve Soylu, C. (2006). Matematik Derslerinde Başarıya Giden Yolda Prolem Çözmenin Rolü. Eğitim Fakültesi Dergisi, 7(11), 97111.

Sweller, J., Clark, R. ve Kirschner, P. (2010). “Teaching General Problem-Solving Skills Is Not a Substitute for, or a Viable Addition to, Teaching Mathematics," Notices of the American Mathematical Society, 57, no. 10

Xenofontos, C. ve Andrews, P. (2008). Teachers' Beliefs about Mathematical Problem Solving, Their Problem Solving Competence and the Impact on Instruction: A Case Study of Three Cypriot Primary Teachers. 11th International Congress on Mathematical Education. 6-13 July. Mexico.

Uğurluoğlu, E. (2008). İlköğretim Öğrencilerinin Matematik Ve Problem Çözmeye İlişkin İnançlar İle Tutumlarının Bazı Değişkenler Açısından İncelenmesi. (Yayınlanmamış yüksek lisans tezi). Eskişehir Osmangazi Üniversitesi/Fen Bilimler Enstitüsü, Eskişehir.

Yıldırım, A. ve Şimşek, H. (2005). Sosyal Bilimlerde Nitel Araştırma Yöntemleri (Genişletilmiş 5. baskı). Ankara: Seçkin Yayıncllık.

Yılmaz, K. (2007). Öğrencilerin Epistemolojik ve Matematik Problemi Çözümlerine Yönelik İnançlarının Problem Çözme Sürecine Etkisinin Araştırılması. (Yayınlanmamış yüksek lisans tezi). Marmara Üniversitesi/Eğitim Bilimleri Enstitüsü, İstanbul. 